\title{
Visible Spectrophotometric Determination of Metochlopramide Hydrochloride at Trace Levels in Various Samples after Cloud Point Extraction Using Derivatization Reaction
}

\author{
ZUHAIR A-A KHAMMAS ${ }^{*}$ and HAWRAA M. ABDULKATEEM \\ Department of Chemistry, College of Science for Women, University of Baghdad, \\ Jadiyriah, Baghdad, Iraq \\ saifkhammas@gmail.com
}

Received 22 January 2017 / Accepted 24 February 2017

\begin{abstract}
Two new methods have been established based on extraction and determination of drug metochlopramide hydrochloride (MCP.HCl) in different samples, by using surfactant as extracting medium and visible spectrophotometer as a detection system. The methods are depended on the reaction of diazonium $\mathrm{MCP} . \mathrm{HCl}$ with (A) 8-hydroxyquinoline (8-HQ) and (B) phenylephrine hydrochloride (PHE) in alkaline media to form azo dyes products which can be extracted into micelles of triton $\mathrm{x}-114$ and drug MCP.HCl determined in the visible region at $\lambda_{\max }$ of 530 and $490 \mathrm{~nm}$ respectively. All parameters that influence on diazotization coupling reaction between the drug and reagents as well as for extraction efficiency of the colored products are examined by using the conventional optimization. The results have shown that the enrichment factors of 217.7 and 26.98 fold, achieving the detection limit of 0.019 and $0.24 \mu \mathrm{gmL}^{-1}$, with linear range of $0.1-0.7 \mu \mathrm{gmL}^{-1}$ $(\mathrm{r}=0.9996)$ and $0.5-11.0 \mu \mathrm{gmL}^{-1}(\mathrm{r}=0.9998)$ for the drug $\mathrm{MCP} . \mathrm{HCl}$ in method A and B respectively. The mean percent recovery was $98.20 \pm 2.71 \%$ in drug vial sample and $99.37 \pm 2.41 \%$ in tap water and the precision (RSD\%) ranged between $3.53-1.21 \%$ and $0.97-0.11 \%$ for $\mathrm{MCP} . \mathrm{HCl}$ in method $\mathrm{A}$ and $\mathrm{B}$, respectively. The developed methods were compared with reported methods published in chemical literature and used for the determination of $\mathrm{MCP} . \mathrm{HCl}$ in different samples.
\end{abstract}

Keywords: Metochlopramide hydrochloride, 8-Hydroxyquinoline, Phenylephrine hydrochloride, Diazotization-coupling reaction, Cloud point extraction, Visible- spectrophotometry

\section{Introduction}

The determination of medicaments in the biological and environmental samples, not only in drug formulations, has become of urgent issues for the time being. On the contrary of the rational use of the drug, the misuse of medicaments is becoming a familiar with peoples especially for those countries that do not have strict and restrictive legislation in dealing with drugs which lead to the risk of dire consequences for the people. Thus cases of abuse of drugs when submit to the laboratories cause a problem to the analysts in obtaining rapid and 
reliable results ${ }^{1}$. Consequently, standard and selective analytical protocol is a must, for the quantification of drugs in the biological samples for the purposes of quality control and more significantly for the clinical diagnosis ${ }^{2}$. On the other hand, there are numerous human and veterinary medicaments are released to the environment by various routes which ultimately enter surface waters and this fact was confirmed by many studies ${ }^{3,4}$. Thus this problem undoubtedly poses environmental risks in which humans, animals and microorganisms are affected. Since these contaminants occur at low concentration levels, so they require a separation from their matrices and determination by using sophisticated instrumentation characterized with high selectivity and reliability.

Several analytical techniques have been used for the determination of the drugs in the above matrices including RP-HPLC ${ }^{5,6}$, SPE-HPLC ${ }^{7}$ HPLC/MS $^{8,9}$, HPLC/MS/MS ${ }^{10,11}$ UPLC$\mathrm{MS} / \mathrm{MS}^{12}$, GC/MS ${ }^{13}$, voltammetric and polarographic methods ${ }^{14-17}$ and FIA-CL ${ }^{18,19}$. Although these techniques are sophisticated and have a high detection power but they are relatively expensive and not always available in all laboratories. Recently, the combination of UV-Vis spectrophotometry with cloud point extraction (CPE) has proved to offer a promising alternative method of improving conventional analytical procedure toward easy, simple, eco-friendly and inexpensive routine analyses of the pharmaceuticals in different matrices instead of using expensive instrumentations ${ }^{20-23}$.

The efforts in this trend are continuing to design new CPE procedures according to the successful attempts that are made for the first time in our research groups in exploiting the cloud point extraction (CPE) and the adoption of derivatization reactions in converting organic compounds (drugs and pesticides) to the colored derivatives that capable to be extracted by using surfactant as an extracting medium ${ }^{24-27}$. In the present work, drug metoclopramide hydrochloride (Figure 1) is selected as a model for designing new CPE procedures after using two coupling agents for its extraction and determination by visible spectrophotometry. The drug is chemically IUPAC named as 4-amino-5-chloro- $N$-(2(diethylamino)ethyl)-2-methoxybenzamide and widely used in prevention and relief of nausea and vomiting as well as in combination with chemotherapy, where drugs such as cisplatin and other cytotoxic agents, are highly emetic ${ }^{28,29}$.<smiles>CCN(CC)CCNC(=O)c1cc(Cl)c(N)cc1OC</smiles>

Figure 1. Chemical structure of metoclopramide hydrochloride $\left(\mathrm{C}_{14} \mathrm{H}_{23} \mathrm{Cl}_{2} \mathrm{~N}_{3} \mathrm{O}_{2} \cdot \mathrm{HCl}\right.$; M.wt.354.3 $\mathrm{g} \mathrm{mol}^{-1}$ )

\section{Experimental}

The main instrument employed in this work was a Shimadzu double-beam UV-Vis spectrophotometer model UV-1800 (Kyoto, Japan) equipped with $5 \mathrm{~mm}$ optical path cell for scanning the absorption spectrum of the resulting colored products beside the absorbance measurements of the target drug under study. Thermostatic water bath model WNB7-45 experts (England) was used throughout the CPE experiments. For solution pH measurements, a portable $\mathrm{pH} / \mathrm{mV} / \mathrm{C}$ meter HI 83141 (HANNA, Romania) was used.

\section{Reagents and materials}

The chemicals used in this work were of high purity and used as received. Doubly distilled water was used for the preparation of all solutions and for the final rinsing of glassware. A pure grade $(95.5 \%)$ of metoclopramide hydrochloride (MCP) was obtained from Sigma Aldrich (USA). 
The diazonium salt of MCP stock solution $\left(1000 \mu \mathrm{gmL}^{-1}\right)$ was daily prepared by dissolving $0.10 \mathrm{~g}$ in minimum amount of water and then $1.5 \mathrm{~mL}$ of $\mathrm{HCl}(1.0 \mathrm{M})$ added with stirring at $5{ }^{\circ} \mathrm{C}$ in ice bath. After $5 \mathrm{~min}$, a $0.0240 \mathrm{~g}$ of sodium nitrite (Sigma-Aldrich, USA ) was added to the mixture while keeping in ice bath and shaking well for $5 \mathrm{~min}$, then the solution made up to the mark in a $100 \mathrm{~mL}$ volumetric flask with water. The working solutions were daily prepared by appropriate dilutions in water. 8-hydroxyquinoline (8-HQ,) at concentration of $1.0 \mathrm{mM}$ was prepared by dissolving $0.0145 \mathrm{~g}$ in a little amount of ethanol and diluted to $100 \mathrm{~mL}$ with same solvent in $100 \mathrm{~mL}$ volumetric flask. An amount of $2.4 \mathrm{mM}$ phenylephrine hydrochloride (PHE, 95.5\%, Sigma-Aldrich, USA) was prepared by dissolving $0.05 \mathrm{~g}$ in a minimum amount of water diluted to $100 \mathrm{~mL}$ with water in $100 \mathrm{~mL}$ volumetric flask. Triton x-114 (purity $>99.9 \%$ ), was purchased from AMRESCO LLC (Solon, USA). A $10 \%(\mathrm{v} / \mathrm{v})$ of triton $\mathrm{x}-114$ is prepared by diluting $10 \mathrm{~mL}$ with water in a $100 \mathrm{~mL}$ volumetric flask. An amount of $0.5 \mathrm{M}$ of sodium hydroxide (BDH), sodium carbonate (BDH) and potassium hydroxide (Riedel De-Haenag, Germany) were prepared by dissolving an appropriate amount of base in water. An amount of $0.5 \mathrm{M}$ ammonia (BDH, England) solution was prepared from concentrated solution $(13.4 \mathrm{M})$ by transferring $3.73 \mathrm{~mL}$ into a $100 \mathrm{~mL}$ volumetric flask and diluted to mark with water. A $1.0 \mathrm{M}$ of $\mathrm{HCl}(\mathrm{BDH}, \mathrm{UK})$ is prepared from concentrated $\mathrm{HCl}$ solution $(11.98 \mathrm{M}$ ) by transferring $8.35 \mathrm{~mL}$ into $100 \mathrm{~mL}$ volumetric flask and diluted to mark with water.

\section{Recommended CPE procedure}

\section{Method A}

In $10 \mathrm{~mL}$ volumetric flasks, an amount of MCP standard or sample solutions to the range of 0.3-0.7 $\mu \mathrm{g} \mathrm{mL} \mathrm{m}^{-1}, 0.02 \mathrm{~mL}$ of $1.0 \mathrm{mM} 8-\mathrm{HQ}$ and $0.01 \mathrm{~mL}$ of $0.5 \mathrm{M} \mathrm{KOH}$ were added. The content of each flask was kept aside for $5 \mathrm{~min}$ at room temperature to complete the reaction. Then, $0.4 \mathrm{~mL}$ of triton $\mathrm{x}-114(10 \%)$ was added to each flask, mixed well and diluted to mark with water. The content of each flask was transferred into a $10 \mathrm{~mL}$ centrifuging tubes and kept in the thermostatic bath at $55{ }^{\circ} \mathrm{C}$ for $10 \mathrm{~min}$. Separation of the phases was done by centrifugation at $3500 \mathrm{rpm}$ for $20 \mathrm{~min}$. The aqueous phase was easily removed by pipette. The surfactant-rich phase that contains the colored product was dissolved in $1.0 \mathrm{~mL}$ ethanol and the absorbance of the product measured at $\lambda_{\max }$ of $530 \mathrm{~nm}$ against a reagent blank prepared under similar conditions. The remaining MCP in aqueous solution was determined by traditional spectrophotometry at $\lambda_{\max }$ of $274 \mathrm{~nm}$ in order to determine the distribution ratio (D) and extraction efficiency $(\% \mathrm{E})$.

\section{Method B}

To a $10 \mathrm{~mL}$ volumetric flasks, $0.18 \mathrm{~mL}$ of $2.4 \mathrm{mM}$ PHE was ipette to each flask followed an amount of diazotized MCP standard $\left(0.5-11.0 \mu \mathrm{gmL}^{-1}\right)$ or sample solutions in the range of a calibration curve, $0.01 \mathrm{~mL}$ of $0.5 \mathrm{M} \mathrm{NaOH}$ solution were added, mixed well and the solutions were kept aside for $15 \mathrm{~min}$ for complete reaction. After the formation of azo dye product, $1.4 \mathrm{~mL}$ of $10 \% \mathrm{TX}=114$ was added, mixed well and each flask diluted to mark with water. The content of each flask was transferred into a $10 \mathrm{~mL}$ centrifuging tubes and kept in the thermostatic bath at $55{ }^{\circ} \mathrm{C}$ for $10 \mathrm{~min}$, After the separation of the two phases, each tube was put in a centrifuge at $3500 \mathrm{rpm}$ for $20 \mathrm{~min}$, then SRP of each tube was dissolved in $1.0 \mathrm{~mL}$ of ethanol and the azo dye was measured at wavelength maximum of $490 \mathrm{~nm} v s$. blank prepared in a similar manner without MCP.HCl solution. The remaining MCP in aqueous solution was determined by traditional spectrophotometry at $\lambda_{\max }$ of $274 \mathrm{~nm}$ in order to determine the distribution ratio (D) and extraction efficiency $(\% \mathrm{E})$. 


\section{Preparation of samples}

Pharmaceuticals

Three selected medicaments from different producers purchased from the drugstores in Baghdad/Iraq in the form of ampoules containing $10 \mathrm{mg}$ per $2 \mathrm{~mL}$ of active $\mathrm{MCP} . \mathrm{HCl}$ were analyzed via the direct dilution of the ampoules with water and subjected to recommended $\mathrm{CPE}$ procedure for MCP (method $\mathrm{A}$ and $\mathrm{B}$ ) and the content of drug was measured spectrohotometrically at $\lambda_{\max }$ of 530 and $490 \mathrm{~nm}$ respectively for five repeated measurements.

\section{Serum}

Blood samples were randomly selected from five normal volunteers who were not taking any drug, via withdrawing $5 \mathrm{~mL}$ from the vein using a medical syringe. Each sample was transferred immediately into a sterilized plastic centrifugal tube, kept aside for $15 \mathrm{~min}$ and centrifuged at $6000 \mathrm{rpm}$ for $10 \mathrm{~min}$ to separate the serum from the whole blood. To ensure a complete separation of blood matrix from each sample, $50 \mu \mathrm{g}$ of trichloroacetic acid was added and the content re-centrifuged for $10 \mathrm{~min}$ and pure serum samples were kept in refrigerator until analyzed. All serum were thawed and spiked with $0.7 \mu \mathrm{g} \mathrm{mL} L^{-1}$ diazotized $\mathrm{MCP}$ and subjected to the recommended $\mathrm{CPE}$ procedure (method A). The content of MCP drug in the colored product was determined spectrophotometrically at $530 \mathrm{~nm}$.

\section{Urine}

Urine samples were randomly selected from five normal volunteers who were not taking any drug, via collecting $10 \mathrm{~mL}$ from each person. Each sample was transferred immediately into a glass centrifugal tube and centrifuged at $6000 \mathrm{rpm}$ for 10, filtered and the filtrate of each sample was gently heated to remove all residual protein and salts. Each urine sample was spiked with $0.1,0.3$ and $0.7 \mu \mathrm{gmL}^{-1}$ diazotized $\mathrm{MCP}$ and subjected to the recommended $\mathrm{CPE}$ procedure (method A). The content of MCP drug in the colored product was determined spectrophotometrically at $530 \mathrm{~nm}$.

\section{Water samples}

About one liter of various water samples was randomly collected from different sources such as Tigris River in Baghdad, water well from local house and Baltic Sea which passes in Denmark. The samples were kept in refrigerator until analyzed. $5.0 \mathrm{~mL}$ of water was taken from each sample in a centrifugal tube, then centrifuged at $3500 \mathrm{rpm}$ for $15 \mathrm{~min}$, filtered and $1.0 \mathrm{~mL}$ of each filtrate was spiked with $1.0,3.0$ and $6.0 \mu \mathrm{gmL}^{-1}$ of diazotized MCP.HCl followed the recommended CPE procedure for MCP.HCl drug (Method B). The content of MCP drug in the colored product was determined spectrophotometrically at $490 \mathrm{~nm}$.

\section{Statistical analysis}

Minitab version 17 (Minitab Inc., State College, PA, USA) ${ }^{30}$ and Excel 2010 (Microsoft Office $\left.{ }^{\circledR}\right)$ were was to carry out all statistical calculations such as regression and correlation analysis, ANOVA and significance tests.

\section{Results and Discussion}

\section{Preliminary studies}

The first attempt of this study was focused on the possibility the reaction of diazotized MCP drug with 8-HQ or PHE reagents in basic medium by taking an aliquot of $10 \mathrm{~mL}$ containing a fixed concentrated of diazotized MCP $\left(0.3 \mu \mathrm{gmL}^{-1}\right), 1.0 \times 10^{-5} \mathrm{M} 8-\mathrm{HQ}$ and $3.0 \times 10^{-3} \mathrm{M}$

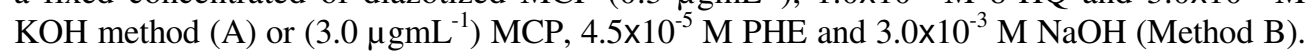
Each mixture was left for $5 \mathrm{~min}$ for the complete reaction and then $1.0 \mathrm{~mL}$ of $10 \%$ triton $\mathrm{x}-114$ 
was added. The solution was subjected to heat in a controlled-temperature water bath at a temperature of $60{ }^{\circ} \mathrm{C}$ for $15 \mathrm{~min}$ and the cloud point layer which contains a colored product was separated by centrifuge, dissolved in $1.0 \mathrm{~mL}$ ethanol then scanned spectrophotometrically from 300-1100 $\mathrm{nm}$ against the reagent blank. The results revealed that the two azo dye products gave maximum absorption signals at 530 and $490 \mathrm{~nm}$ for method A and B respectively as shown in Figures $2 \mathrm{a}$ and $3 \mathrm{a}$. The absorption spectra of the two azo dye products formed in method A and B were also recorded against the corresponding reagent blank after obtaining optimum conditions according to the recommended CPE procedures (A and B). Figure $2 \mathrm{~b}$ shows the absorption spectrum of the extracted MCP- $8 \mathrm{HQ}$ product against reagent blank $(320 \mathrm{~nm})$, exhibiting again $\lambda_{\max }$ of $530 \mathrm{~nm}$ and giving a molar absorptivity of $1.29 \times 10^{6} \mathrm{~L}_{\mathrm{mol}}{ }^{-1} \mathrm{~cm}^{-1}$. Figure $3 \mathrm{~b}$ shows the absorption spectrum of the extracted MCP-PHE product against blank $(340 \mathrm{~nm})$, exhibiting $\lambda_{\max }$ of $490 \mathrm{~nm}$ and giving a molar absorptivity of $1.64 \times 10^{5} \mathrm{~L} \mathrm{~mol}^{-1} \mathrm{~cm}^{-1}$. While a pure MCP solution displays absorption maximum at 274 . Consequently, the wavelength maxima at 530 and $490 \mathrm{~nm}$ for the two colored-products were used throughout this study for micro amounts of MCP.HCl drug.

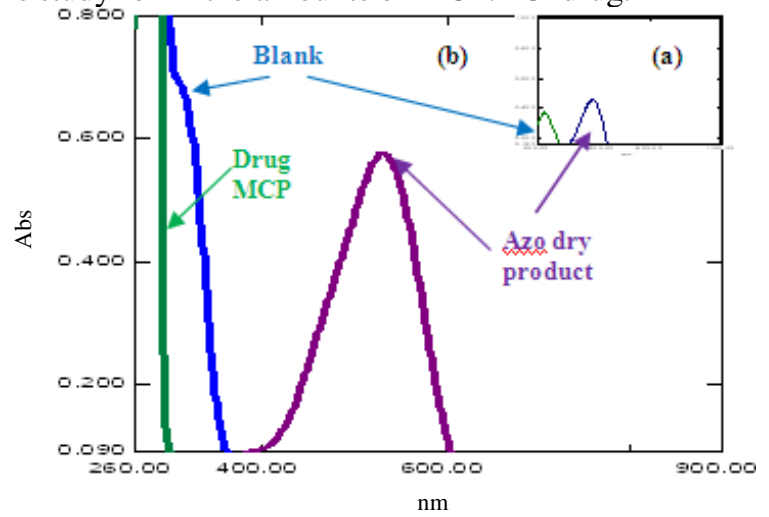

Figure 2(a). Absorption spectra of the azo dye product (A) against reagent blank before $\mathrm{CPE}$ and (b) The azo dye product (B) after CPE at optimum conditions: $0.3 \mu \mathrm{gmL}^{-1}$ $\mathrm{MCP} . \mathrm{HCl}, 2.0 \times 10^{-6} \mathrm{M}$ 8-HQ, $0.5 \mathrm{mM} \mathrm{KOH}, 0.4 \%$ TX-114

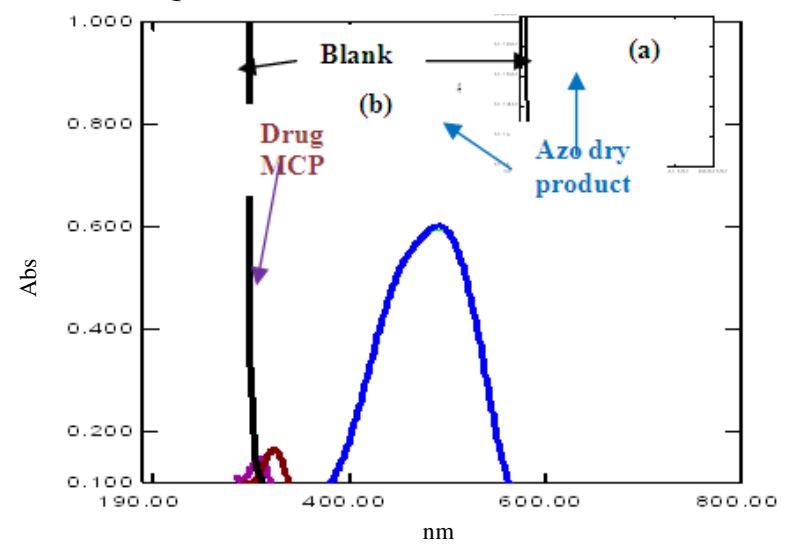

Figure 3(a). Absorption spectra of the azo dye product (B) against reagent blank before CPE and (b) The azo dye product (B) after CPE at optimum conditions: $3.0 \mu \mathrm{gmL}^{-1}$ $\mathrm{MCP} . \mathrm{HCl} ; 4.32 .0 \times 10^{-5} \mathrm{PHE}, 0.5 \mathrm{mM} \mathrm{NaOH}, 1.4 \% \mathrm{TX}-114$ 
The impact of different alkaline media such $\mathrm{NaOH}, \mathrm{KOH}, \mathrm{NH}_{4} \mathrm{OH}$ and $\mathrm{Na}_{2} \mathrm{CO}_{3}$ at $3.0 \mathrm{mM}$ concentration level was tested to select the best type of alkaline medium that gives the best absorption signal for the azo dye products by taking the same concentrations of the diazonium drug and reagents as mentioned above and the absorbance of the colored-product was measured at 530 and $490 \mathrm{~nm}$ respectively. It was shown that the best alkaline mediums were $\mathrm{KOH}$ and $\mathrm{NaOH}$ for method $\mathrm{A}$ and $\mathrm{B}$ respectively because they gave the best sensitivity of the azo dye products.

The influence of reaction time for the formation of the azo dye products was also examined between 0-30 min by using the same concentration of diazonium MCP and reagents without subjecting the reaction mixture to CPE. It was appeared that the best time giving a better absorption signal for the colored products was 5 and $15 \mathrm{~min}$ for method A and B respectively. All these findings were adopted in the optimization conditions of CPE for both reactions.

\section{Optimization of CPE}

Number of significant experimental factors that potentially affecting the extraction efficiency, enrichment factor and sensitivity of detection have been carried out for both derivatization reaction systems. These factor such as; the effect of reagents concentration, alkaline medium, amount of surfactant, equilibration temperature and incubation time have been systematically optimized in detail by using the univariant method in which one factor is altered while the others fixed. In the following experiments, a specified concentration of diazotized MCP.HCl standard solution was taken to $10 \mathrm{~mL}$ volumetric flasks into which the reagents added and diluted to mark with water followed CPE procedure. The absorbance of a series of solutions was measured at 530 and $490 \mathrm{~nm}$ versus reagent blank for method A and B respectively.

\section{Effect of reagent concentration}

The influence of concentration of 8-HQ and PHE was studied using different volumes of $1.0 \mathrm{mM}$ and $2.4 \mathrm{mM}$ of solutions respectively. Figure 4 shows that the optimum volume of $1.0 \mathrm{mM}$ 8-HQ was of $0.02 \mathrm{~mL}\left(2.0 \times 10^{-3} \mathrm{mM}\right.$ in $10 \mathrm{~mL}$ final solution) and $0.8 \mathrm{~mL}$ of $2.4 \mathrm{mM}$ PHE (0.0432 mM in $10 \mathrm{~mL}$ final solution) were enough to give maximum absorbance, high stability of the colored products and subsequently the best extraction efficiency for the determination of MCP drug in the two reaction systems. At lower or higher concentrations of each reagent than optimal, less intensely colored products were observed so any excessive amount of reagent was not needed. Therefore, $0.02 \mathrm{~mL}$ of $1.0 \mathrm{mM} 8-\mathrm{HQ}$ and $1.8 \mathrm{~mL}$ of $2.4 \mathrm{mM}$ PHE in $10 \mathrm{~mL}$ solution were used in further experiments.

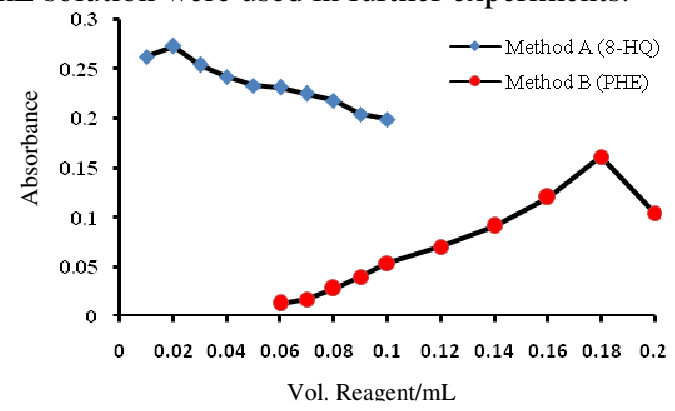

Figure 4. Effect of reagent concentration on the absorbance of the azo dye products [Conditions: method A; MCP $\left(0.3 \mu \mathrm{gmL}^{-1}\right)$; 8-HQ (0.01-1.1.0 $\mathrm{mL}$ of $\left.1 \mathrm{mM}\right)$; KOH (3.0 mM) reaction time (5 min); TX-114 (1.0\%); CP temperature $\left(60{ }^{\circ} \mathrm{C}\right)$; incubation time $(15 \mathrm{~min})$. Method B: MCP (3.0 $\left.\mathrm{ggmL}^{-1}\right)$; PHE (0.06-0.2 $\mathrm{mL}$ of $\left.2.4 \mathrm{mM}\right)$; NaOH (3.0 mM); reaction time (15 min); TX-114 (1.0\%); CP temperature $\left(60^{\circ} \mathrm{C}\right)$; incubation time (20 min)] 


\section{Effect of alkaline medium}

In preliminary tests, it was shown that the coupling of the two reagents with diazonium salt of MCP drug occur in alkaline medium to form azo dyes and needs too strong basic medium to produce intense colored dye such $\mathrm{NaOH}$ and $\mathrm{KOH}$. Therefore, the effect of different volumes of $0.5 \mathrm{M} \mathrm{KOH}$ and $\mathrm{NaOH}$ was investigated by varying the volume between (0.01-0.1 mL) keeping other variables fixed. The results are displayed in Figure 5. The data revealed that the optimum volume was $0.01 \mathrm{~mL}$ of $0.5 \mathrm{M} \mathrm{KOH}$ and $\mathrm{NaOH}(0.5 \mathrm{mM}$ in $10 \mathrm{~mL}$ solution) gave a maximum absorption signal of the colored azo dyes for method $\mathrm{A}$ and $\mathrm{B}$ respectively, which is used in the next experiments.

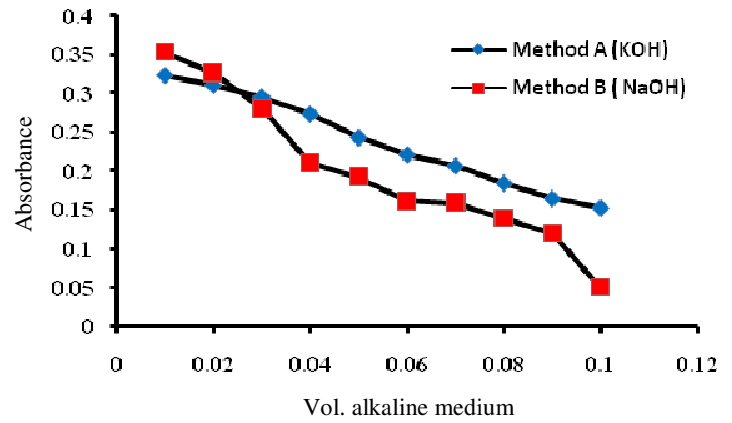

Figure 5. Effect of alkaline medium concentration on the absorbance of the azo dye products [Conditions: method A; $M C P\left(0.3 \mu g m L^{-1}\right) ; 8-H Q\left(2.0 \times 10^{-3} \mathrm{mM}\right) ; \mathrm{KOH}(0.01-0.1 \mathrm{~mL}$ of $0.5 \mathrm{M})$ reaction time (5 $\mathrm{min})$; $\mathrm{TX}-114(1.0 \%)$; $\mathrm{CP}$ temperature $\left(60^{\circ} \mathrm{C}\right)$; incubation time (15 min). Method B: MCP (3.0 $\left.\mu \mathrm{g} \mathrm{mL} \mathrm{L}^{-1}\right) ;$ PHE (0.0432 $\left.\mathrm{mM}\right) ; \mathrm{NaOH}(0.01-1.0 \mathrm{~mL}$ of 0.5 M); reaction time (15 min); TX-114 (1.0\%); CP temperature $\left(60^{\circ} \mathrm{C}\right)$; incubation time (20 min)]

\section{Effect of triton $x$-114 amount}

Different volumes ranges of triton $\mathrm{x}-114(10 \% \mathrm{v} / \mathrm{v})$ were used in this study at previously optimum conditions as shown in Figure 6. It was shown that the absorbance for both azo dyes increases gradually with increasing the triton $\mathrm{x}-114$ amount and reached maximum at 0.4 and $1.4 \mathrm{~mL}$ of $10 \% \mathrm{TX}-114$ for method A and B respectively. Thus, these values were selected as optimal volumes and used in the proposed methods (A and B) for the detection of MCP drug.

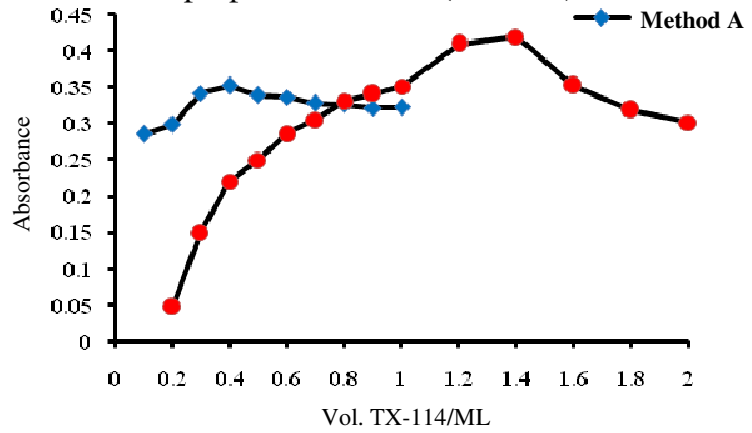

Figure 6. Effect of triton $\mathrm{x}-114$ amount on the absorbance of the azo dye products [Conditions: method A; MCP $\left(0.3 \mu \mathrm{gmL}^{-1}\right) ; 8-H Q\left(2.0 \times 10^{-3} \mathrm{mM}\right) ; \mathrm{KOH}(0.5 \mathrm{mM})$ reaction time (5 min); TX-114 (0.1-1.0 of 10\%); CP temperature (60 $\left.{ }^{\circ} \mathrm{C}\right)$; incubation time (15 min). Method B: $M C P\left(3.0 \mu \mathrm{g} \mathrm{mL} L^{-1}\right) ; P H E(0.0432 \mathrm{mM}) ; \mathrm{NaOH}(0.5 \mathrm{mM})$; reaction time (15 min); TX-114 (0.2-2.0 of 10\%); CP temperature $\left(60^{\circ} \mathrm{C}\right)$; incubation time (20 min)] 


\section{Effect of equilibration temperature}

Figure 7 shows the variation on the absorption signal via varying the temperature between 25 to $70{ }^{\circ} \mathrm{C}$ keeping other parameters fixed. It found that the maximum absorption signal of the target analyte (MCP) in both methods was achieved at $55^{\circ} \mathrm{C}$, due to a high number of micelles formed in cloud point layer leading the entire transfer of the azo dye products into a surfactant-rich phase which maximizes the sensitivity. A remarkable decrease of the absorbance response was observed thereafter, probably due to the instability or dissociation of the azo dye products at a higher temperature than optimal. Therefore, a temperature of $55{ }^{\circ} \mathrm{C}$ was selected and used as optimal in the general CPE procedures of both methods.

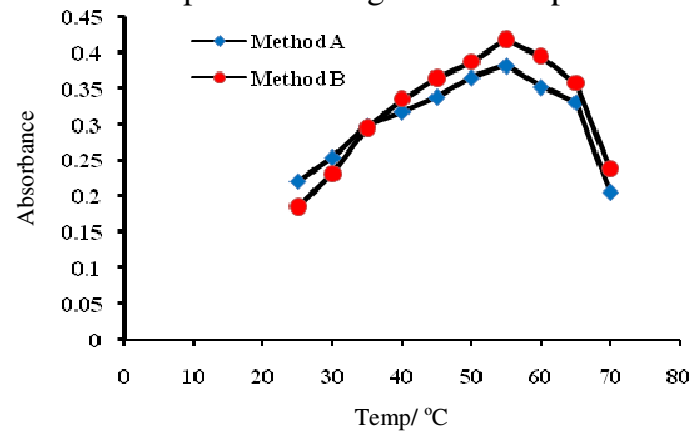

Figure 7. Effect of equilibration temperature on the absorbance of the azo dye products [Conditions: method A; $M C P\left(0.3 \mu \mathrm{gmL}^{-1}\right) ; 8-\mathrm{HQ}\left(2.0 \times 10^{-3} \mathrm{mM}\right) ; \mathrm{KOH}(0.5 \mathrm{mM})$ reaction time (5 min); TX-114 (0.4\%) CP temperature $\left(25-70{ }^{\circ} \mathrm{C}\right)$; incubation time (15 min). Method B: MCP (3.0 $\left.\mu \mathrm{gmL}^{-1}\right)$; PHE (0.0432 $\left.\mathrm{mM}\right) ; \mathrm{NaOH}(0.5 \mathrm{mM})$; reaction time (15 min); TX-114 (1.4\%); CP temperature $\left(25-70^{\circ} \mathrm{C}\right)$; incubation time $\left.(20 \mathrm{~min})\right]$

\section{Effect of incubation time}

The impact of incubation time on the absorption signals of the two azo dyes products was investigated using different heating times starting from $5 \mathrm{~min}$ until $50 \mathrm{~min}$ at cloud point temperature of $55{ }^{\circ} \mathrm{C}$. The maximum absorption signal was achieved at $10 \mathrm{~min}$ for both MCP-8HQ and MCP-PHE products and gradually decreased thereafter as showed in Figure 8. It was also noted that the centrifugation speed and time of $20 \mathrm{~min}$ at $3500 \mathrm{rpm}$ were suitable for complete the separation of the two phases.

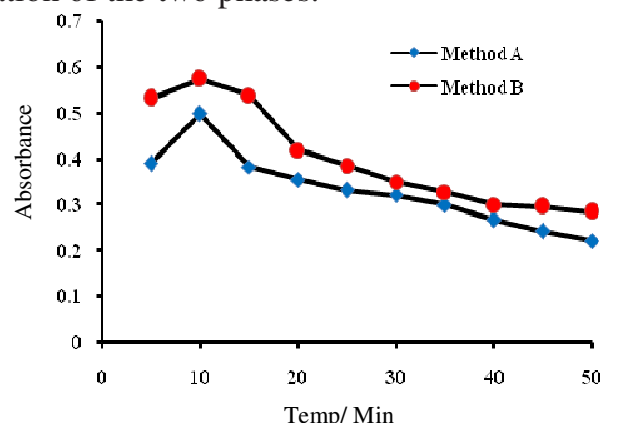

Figure 8. Effect of equilibration temperature on the absorbance of the azo dye products [Conditions: method A; MCP $\left(0.3 \mu \mathrm{gmL}^{-1}\right) ; 8-\mathrm{HQ}\left(2.0 \times 10^{-3} \mathrm{mM}\right) ; \mathrm{KOH}(0.5 \mathrm{mM})$ reaction time (5 min); $T X-114(0.4 \%) C P$ temperature $\left(55^{\circ} \mathrm{C}\right)$; incubation time (5-50 min). Method B: MCP (3.0 $\left.\mathrm{ggmL}^{-1}\right) ; \mathrm{PHE}(0.0432 \mathrm{mM}) ; \mathrm{NaOH}(0.5 \mathrm{mM})$; reaction time (15 min); $\mathrm{TX}-114$ (1.4\%); CP temperature $\left(55^{\circ} \mathrm{C}\right)$; incubation time (5-50 min)] 
Table 1 shows a summary of the optimum values of the experimental variables for the determination of MCP.HCl drug spectrophotometrically at $\lambda_{\max }$ of 530 and $490 \mathrm{~nm}$ by the two proposed methods after CPE.

Table 1. The summary of optimum experimental conditions for the extraction of colored products by $\mathrm{CPE}$ for method $\mathrm{A}$ and $\mathrm{B}$

\begin{tabular}{ccc}
\hline Variable & Method $\mathrm{A}\left(\lambda_{\max }=530\right)$ & Method $\mathrm{B}\left(\lambda_{\max }=490\right)$ \\
\hline $8-\mathrm{HQ}$ & $0.02 \mathrm{~mL}$ of $1.0 \mathrm{mM}$ & - \\
$\mathrm{PHE}$ & & $0.18 \mathrm{~mL}$ of $2.4 \mathrm{mM}$ \\
$\mathrm{KOH}$ & $\mathrm{mL}$ of $0.5 \mathrm{M}$ & - \\
$\mathrm{NaOH}$ & $5 \mathrm{~min}$ & $0.01 \mathrm{~mL}$ of $0.5 \mathrm{M}$ \\
Reaction time & $0.4 \mathrm{~mL}$ of $10 \% \mathrm{TX}=114$ & $1.4 \mathrm{~mL}$ of $10 \% \mathrm{TX}=114$ \\
$\mathrm{TX}-114$ & $55^{\circ} \mathrm{C}$ & $55^{\circ} \mathrm{C}$ \\
Temperature & $10 \mathrm{~min}$ & $10 \mathrm{~min}$ \\
Incubation time & 530 & 490 \\
$\lambda_{\max }$ & &
\end{tabular}

\section{Stiochoimetry of the reaction}

The molar ratio of the two azo dyes products was determined by using the limiting logarithmic method $^{31}$. In this method, two sets of experiments were prepared followed the recommended CPE procedures of both methods. The first set was done by varying the concentration of the each reagent with fixed concentration of $\mathrm{MCP}$, while the second set was conducted by varying the concentration of MCP with fixed concentration of each reagent. The logarithms of the obtained absorbance were plotted as a function of the logarithms of the concentrations of each reagent and $\mathrm{MCP}$ in the first and second sets of experiments, respectively.

The slopes of the fitting lines in both sets of experiments were calculated. In each method, two straight lines were obtained. The values of the slopes of these lines were of 1.838 and 0.858 by method A (Figure 9), indicating the molar ratio of reaction with MCP/8-HQ was considered to be 2:1. Whilst in method B, the values of the slopes of these lines were 1.906 and 0.881 (Figure 10), indicating the molar ratio of reaction with MCP/PHE was also considered to be $2: 1$

$\log \mathrm{A}=10.68+1.838 \log [\mathrm{MCP}]$

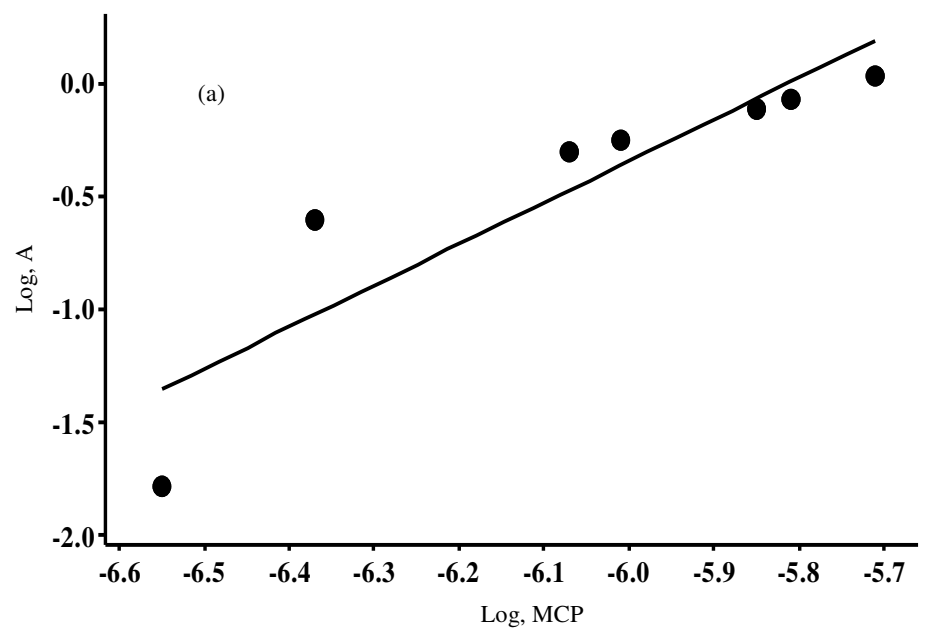




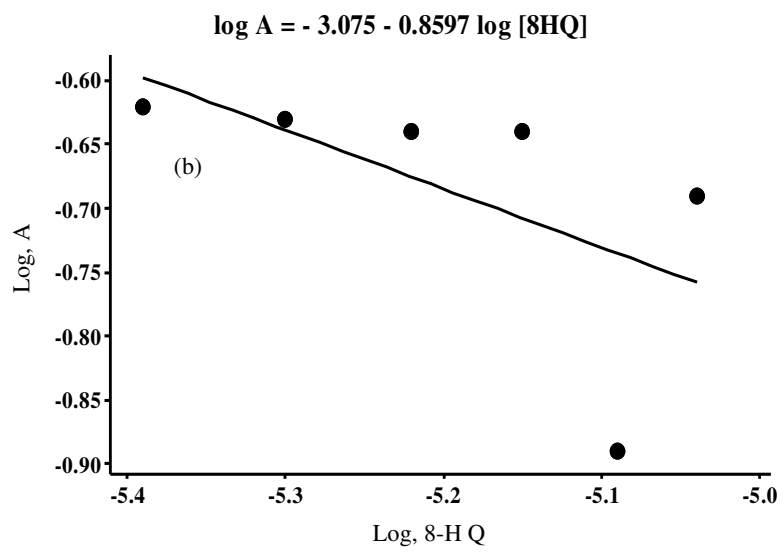

Figure 9(a). Limiting logarithmic plots for the molar reactivity of MCP with 8-HQ: logarithm of absorbance vs. log MCP] at which [8-HQ] is kept constant; (b). Logarithm absorbance $v s . \log [8-\mathrm{HQ}]$ at which [MCP] is kept constant
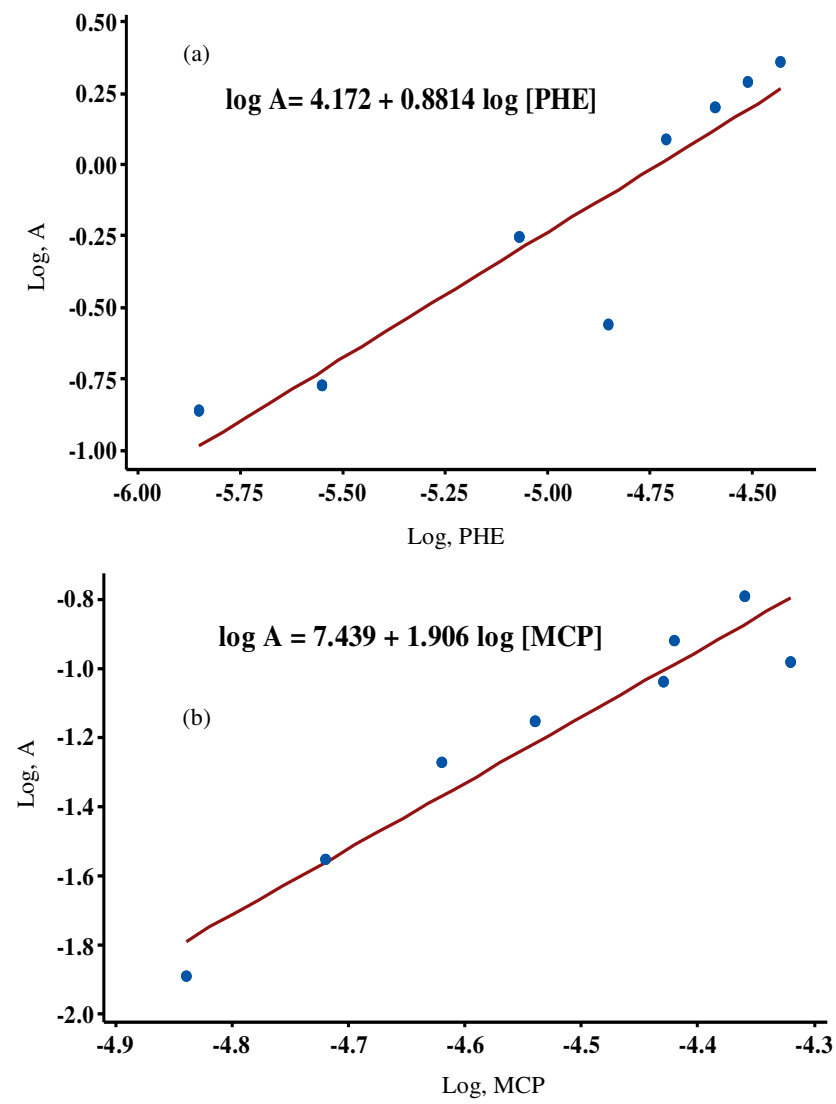

Figure 10(a). Limiting logarithmic plots for the molar reactivity of MCP with 8-HQ: logarithm of absorbance vs. log MCP] at which [PHE] is kept constant; (b). Logarithm absorbance vs. $\log [\mathrm{PHE}]$ at which $[\mathrm{MCP}]$ is kept constant 
Based on the above result (Figures 9 and 10), the two reagents 8-HQ and PHE are coupled with the formed diazonim MCP in alkaline medium to give a deep red color azo dye which exhibited absorption maximum at $530 \mathrm{~nm}$ against reagent blank solution in the method A and a yellow azo dye with absorption maximum at $490 \mathrm{~nm}$ against reagent blank solution in the method B. Thus the most probable pathway for formation of the extracted azo dyes products are preceded by two steps as shown in the Scheme 1 and 2.

\section{Analytical figures of merit}

Under the optimized established conditions (Table 1), seven standard solutions of the drug $\mathrm{MCP}$. $\mathrm{HCl}$ were individually prepared in order to obtain a concentration range from 0.1-0.7 $\mu \mathrm{gmL}^{-1}$ (method A) and 0.5-11.0 $\mu \mathrm{gmL}^{-1}$ (method B) followed the recommended CPE procedures (A and $\mathrm{B}$ ). The fitted calibration curves resulting from plotting the absorbance versus $\mathrm{MCP} . \mathrm{HCl}$ concentration are illusterated in the Figure 11. The statistical evaluation for the two calibration curves reveals that the linear regression equations for both analytes were statistically valid. This because of the ratios $\left(\mathrm{MS}_{\mathrm{reg}} / \mathrm{MS}_{\text {error }}\right)$ for 1 and 6 dof, larger than critical value $\left(\mathrm{F}^{1},{ }_{7}=5.99\right.$ at $\left.\alpha=0.05\right)$, indicating that the predication based on the regression line is satisfactory as listed in Table 2. These regression lines were used to estimate the drug $\mathrm{MCP} . \mathrm{HCl}$ concentration in the selected samples which appears justified on statistical basis.<smiles>[R]c1cc(Cl)c(N)cc1[N+](=O)[O-]</smiles><smiles>[R]c1cc(Cl)c([N+](=O)[O-])cc1OC</smiles><smiles></smiles><smiles>Oc1cccc2cccnc12</smiles><smiles>CCC(C)O</smiles>

$$
\text { 8-HG }
$$<smiles></smiles><smiles>[3H][I-]C(=O)NCCN(CC)CC</smiles>

Scheme 1. The probable reaction mechanism of coupling 8-HQ with diazotized MCP in alkaline medium 


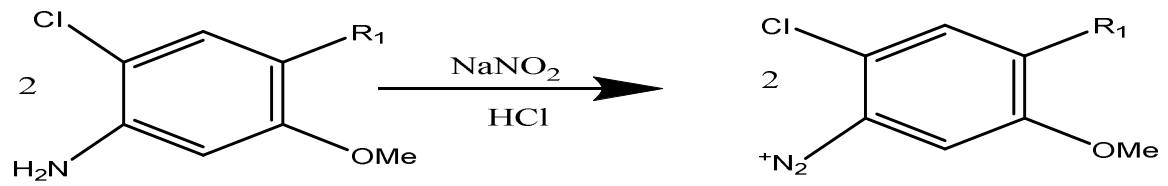

MCP<smiles>[R]c1cc(Cl)c([N+]#N)cc1OC</smiles><smiles>[R2]c1cccc(O)c1</smiles>

PHP

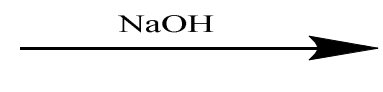<smiles>[R1]c1cc(Cl)c(N=Nc2ccc([R2])c(N=Nc3cc(OC)c([R1])cc3Cl)c2O)cc1OC</smiles><smiles>[Y7][I-]C(C)=O</smiles><smiles>[R16]OCCNC</smiles>

Scheme 2. The probable reaction mechanism of coupling PHE with diazotized MCP in alkaline medium

$$
\begin{gathered}
\text { MCP fitted line plot (Method A) } \\
\text { Abs }=0.02347+1.524[\mathrm{MCP}]
\end{gathered}
$$

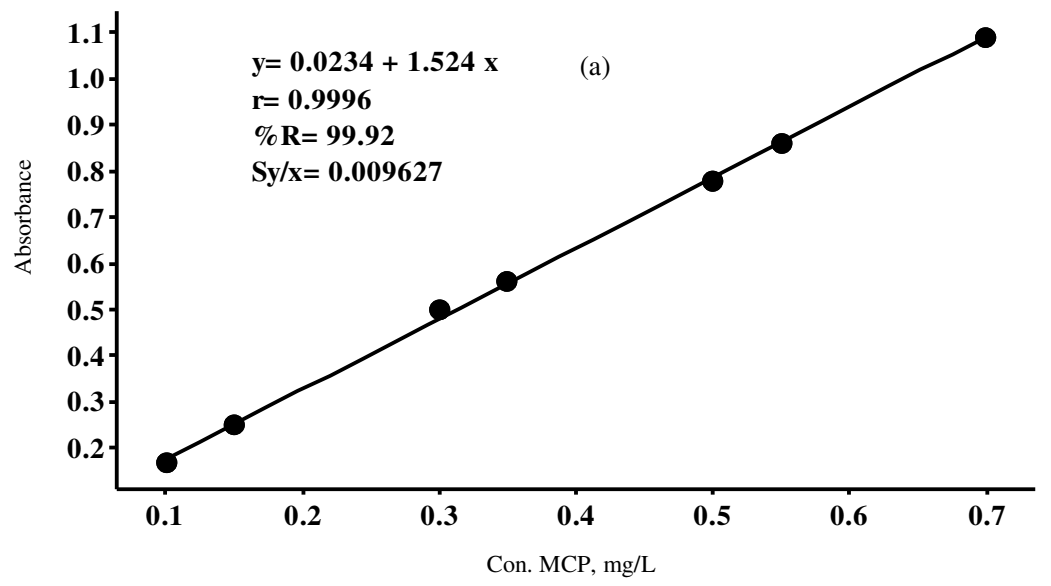




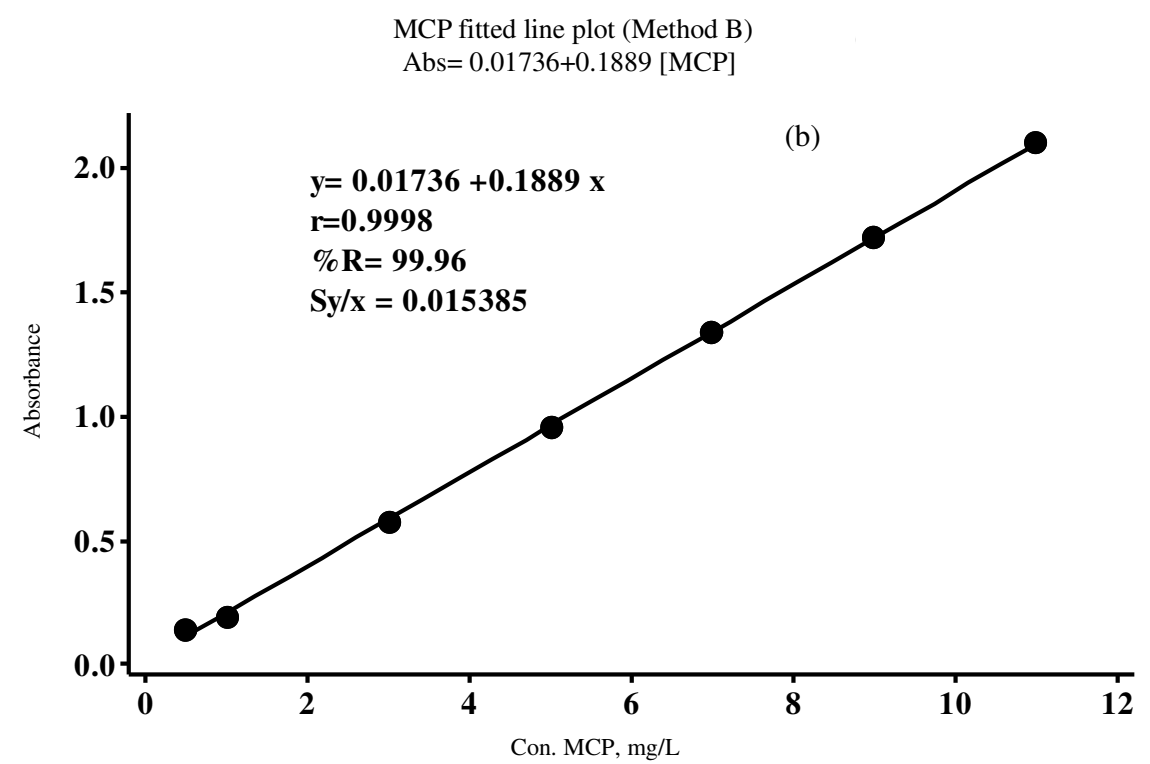

Figure 11. Calibration curves for $\mathrm{MCP} . \mathrm{HCl}$ by the proposed methods

Table 2. Analysis of variance of regression line for MCP of method A and B

\begin{tabular}{ccccccc}
\hline Method & Source & dof & SS & MS & F-value & $\begin{array}{c}\text { Significance } \\
p \text {-value }\end{array}$ \\
\hline \multirow{4}{*}{ A } & Regression & 1 & 0.660314 & 0.660314 & & \\
& Residual (Error) & 5 & 0.000463 & 0.000093 & 7125.47 & 0.000 \\
& Total & 6 & 0.660778 & & & \\
& Regression & 1 & 3.42167 & 3.42167 & & \\
B & Residual (Error) & 5 & 0.00118 & 0.00024 & 14455.28 & 0.000 \\
& Total & 6 & 3.42285 & & & \\
\hline
\end{tabular}

Statistical analytical figures of merit of the proposed methods are summarized in Table 3. The enrichment factors were calculated as the ratio between the slope of a curve obtained using aqueous solutions submitted to the CPE procedure $(\mathrm{y}=1.5240 \mathrm{x}+0.0234 \mathrm{x})$ or $(y=0.1889 x+0.01736)$ and to that obtained without CPE $(y=0.007 x+0.005)$ and found to be of 217.70 and 26.98 fold for method A and B respectively. These enrichment factors allow to detect the drug in aqueous solutions spectrophotometrically at low detection limit of 0.019 (Method A) and $0.24 \mu \mathrm{gmL}^{-1}$ (Method B) which based on the standard deviation of the response (residual standard deviation; $\sigma_{\mathrm{y} / \mathrm{x}}$ ) and the slope(s) of the calibration curve using the equation; $\mathrm{LOD}=3 \sigma_{\mathrm{y} / \mathrm{x}} / \mathrm{s}$. The detection limits obtained by the proposed methods was in harmony with a few but much better than obtained with most reported methods in literature using different diazotization reactions with various chromogenic reagents as listed in Table 4. Moreover, the molar absorptivity $(\varepsilon)$ of $\mathrm{MCP} . \mathrm{HCl}$ was found to be of $1.29 \times 10^{6}$ and $1.64 \times 10^{5} \mathrm{~L} \cdot \mathrm{mol}^{-1} \mathrm{~cm}^{-1}$ for method A and B respectively, indicating the excellent sensitivity of the proposed methods. 
Table 3. Statistical data and analytical figures of merits for AMX by method A and B

\begin{tabular}{|c|c|c|}
\hline Parameter & Method A & Method B \\
\hline Product colour & Red & Orange \\
\hline$\lambda_{\max }, \mathrm{nm}$ & 530 & 490 \\
\hline Regression equation ( 7 points) & $y=1.5240 x+0.0234$ & $y=0.1889 x+0.01736$ \\
\hline Standard deviation of regression line $\left(\mathrm{S}_{\mathrm{y} / \mathrm{x}}\right)$ & 0.009627 & 0.015385 \\
\hline Correlation coefficient $(\mathrm{r})$ & 0.9996 & 0.9998 \\
\hline Coefficient of determination $\left(\mathrm{R}^{2}\right)$ & 99.92 & 99.96 \\
\hline C.L. for the slope $\left(b \pm \mathrm{ts}_{\mathrm{b}}\right)$ at $95 \%$ & $1.5524 \pm 0.12276$ & $0.1889 \pm .0 .010663$ \\
\hline C.L. for the intercept $\left(a \pm t s_{a}\right)$ at $95 \%$ & $0.0234 \pm 0.0526$ & $0.01736 \pm 0.06817$ \\
\hline Beer's law range, $\mu \mathrm{g} \mathrm{mL}^{-1}$ & $0.1-0.7$ & $0.5-11.0$ \\
\hline Limit of detection, $\mu \mathrm{g} \mathrm{mL}^{-1}$ & 0.019 & 0.24 \\
\hline Limit of quantitation, $\mu \mathrm{g} \mathrm{mL}^{-1}$ & 0.063 & 0.81 \\
\hline Sandell's sensitivity, $\mu \mathrm{g} \mathrm{cm}^{-2} \times 10^{-3}$ & 0.6587 & 5.531 \\
\hline Molar absorptivity, L.mol ${ }^{-1} \cdot \mathrm{cm}^{-1}$ & $1.29 \times 10^{6}$ & $1.64 \times 10^{5}$ \\
\hline Composition of the colored product* & $1: 2$ & $1: 2$ \\
\hline $\operatorname{RSD} \%(\mathrm{n}=5)$ & 0.24 at $0.1 \mu \mathrm{gmL}^{-1}$ & 3.60 at $1.0 \mu \mathrm{gmL}^{-1}$ \\
\hline $\operatorname{RSD} \%(\mathrm{n}=5)$ & 0.16 at $0.7 \mu \mathrm{gmL}^{-1}$ & 2.50 at $5.0 \mu \mathrm{gmL}^{-1}$ \\
\hline Preconcentration factor** & 33.3 & 33.3 \\
\hline Enrichment factor & 217.7 & 26.98 \\
\hline Recovery, $\%$ & $97.23 \pm 2.04$ & $98.00 \pm 3.95$ \\
\hline Extraction efficiency, \%E & 99.66 & 98.40 \\
\hline
\end{tabular}

"Limiting logarithmic method ${ }^{* *}$ Preconcentration factor was calculated the ratio of the original sample volume to that extracted volume of surfactant-rich phase

Table 4. Reported methods for the determination of $\mathrm{MCP} . \mathrm{HCl}$ by spectrophotometry after diazotization, oxidative coupling and charge transfer reactions ${ }^{27}$

\begin{tabular}{ccccc}
\hline Coupling reagent used/ Reaction type & $\begin{array}{c}\lambda_{\max }, \\
\mathrm{nm}\end{array}$ & $\begin{array}{c}\text { Linearity } \\
\mu \mathrm{g} \mathrm{mL}\end{array}$ & $\begin{array}{c}\text { LOD, } \\
\mu \mathrm{g} \mathrm{mL}-\end{array}$ & Ref. \\
\hline Dibenzoyl methane/ diazotization & 440 & - & - & 32 \\
Aniline/ diazotization & 410 & $0.5-12.0$ & - & 33 \\
Benzoylacetone/ diazotization & 437 & $0.8-13.2$ & 0.033 & 34 \\
Imipramine hydrochloride/diazotization & 570 & $0.5-5.0$ & 0.014 & 35 \\
p-Dimethylaminocinnamaldehyde/ diazotization & 553 & $4-24$ & 1.120 & 36 \\
Phenol/ diazotization & 463 & $1-20$ & 0.406 & 37 \\
8-Hydroxyquinoline /diazotization & 528 & $0.2-12$ & - & 38 \\
Diphenylamine / diazotization & 530 & $0.3-7.5$ & 0.220 & 39 \\
2,5-Dimethoxyaniline (DMA) /diazotization & 486 & $0.1-12$ & 0.016 & 40 \\
Doxycycline hyclate /diazotization & 452 & $0.1-10$ & 0.012 & 41 \\
Phenoxide / diazotization & 462 & $10-80$ & 3.700 & 42 \\
Malachite green in the presence of 0.01 M & 623 & $2-10$ & 0.087 & 43 \\
chloramine-T and 2 M H HO $_{4}$, & 760 & $\mathrm{Up} \mathrm{to} 100$ & 2.000 & 44 \\
Folin-Ciocalteu/ complex formation & 470 & $2-50$ & 0.368 & 45 \\
9-Chloroacridine / oxidative coupling & 500 & $5-35$ & - & 46 \\
Pyrocatecolin presence of ammonium ceric & 530 & $0.1-0.7$ & 0.019 & This \\
sulphate /Oxidative coupling & 530 & $0.5-11.0$ & 0.24 & work \\
8-HQ /Diazotization & & & &
\end{tabular}




\section{Accuracy and precision study}

Since the certificate reference materials (CRM's) that define exactly the true value of $\mathrm{MCP} . \mathrm{HCl}$ drug are not available, the validity of the proposed methods was evaluated via accuracy test in terms of recovery percentage. The experiments were conducted by spiking different concentrations of MCP.HCl standard solutions to the drug sample prepared from vial produced from GLAND PHRMA LIMITED, (India) and water sample for the method A and $\mathrm{B}$ respectively, keeping the concentration of the drug within the calibration ranges as showed in Table 5. Each spiked sample solution is subjected to the recommended CPE procedures (A and B) with repeated five time measurements. The results in Table 5 revealed that the accuracies of the proposed methods were within the acceptable confidence limits at $\alpha=0.05$, indicative the suggested methods are unbiased and confirmed that they are relatively interferences-free, from drug excipients that might be added during pharmaceutical formulation and water matrices. Hence, the study of interferences from the drug or water matrices is almost an undue. Meanwhile, each spiked sample was repeated five times for precision test in terms of \%RSD and found in the range of $1.21-0.3 .53 \%$ and $0.11-0.97 \%$ for method A and B respectively, indicative a good precision.

Table 5. Accuracy and precision test for $\mathrm{MCP} . \mathrm{HCl}$ in pharmaceutical (Method A) and water samples (Method B)

\begin{tabular}{cccccccc}
\hline Method & Sample & $\begin{array}{c}\text { MCP } \\
\text { Taken, } \\
\mu \mathrm{g} \mathrm{mL} \mathrm{m}^{-1}\end{array}$ & $\begin{array}{c}\text { MCP } \\
\text { Found, } \\
\mu \mathrm{g} \mathrm{mL}^{-1}\end{array}$ & $\begin{array}{c}\text { Rec., } \\
\%\end{array}$ & $\begin{array}{c}\text { Mean } \\
\text { Rec\% } \% \text { C.L. } \\
\text { at } \alpha=0.05\end{array}$ & $\begin{array}{c}\text { Accuracy, } \\
\% \mathrm{E}_{\text {rel }}\end{array}$ & $\begin{array}{c}\text { Precision } \\
(\% \mathrm{RSD}) \\
(\mathrm{n}=5)\end{array}$ \\
\hline A & MCP & 0.1 & 0.098 & 98.0 & & -2.0 & 3.53 \\
& (Indian & 0.3 & 0.287 & 95.6 & $98.20 \pm 3.71$ & -4.4 & 1.74 \\
& vial) & 0.6 & 0.606 & 101.0 & & -1.0 & 1.21 \\
& Spiking & 1.0 & 1.03 & 103.0 & & 3.0 & 0.97 \\
B & water & 3.0 & 2.87 & 95.6 & $99.37 \pm 2.41$ & -4.4 & 0.34 \\
& sample & 6.0 & 5.97 & 99.5 & & -0.5 & 0.11 \\
\hline
\end{tabular}

Table 6. Determination of MCP.HCl drug in pharmaceuticals by the proposed method (A) and statistical comparison with quoted values

\begin{tabular}{|c|c|c|c|c|}
\hline $\begin{array}{l}\text { Commercial name } \\
\text { and content }\end{array}$ & $\begin{array}{l}\text { Practical content } \\
\quad(\mathrm{mg} / 2 \mathrm{~mL}) \\
\text { (proposed method) }\end{array}$ & $\begin{array}{c}\mathrm{t}=(\overline{\mathrm{x}-\mu}) \sqrt{\mathrm{n}} / \mathrm{s} \\
\text { Proposed method } V s \text {. } \\
\text { claimed value at } 95 \% \text { C.I. }\end{array}$ & $\% \mathrm{E}_{\text {rel }}$ & $\begin{array}{c}\% \text { RSD } \\
(n=3)\end{array}$ \\
\hline \multicolumn{5}{|c|}{ Metoclopramide - METAMID 9.80} \\
\hline injection ((IBN HAYYAN & 9.54 & $\mathrm{t}_{\mathrm{cal}}=0.80$ & \multirow{3}{*}{-0.15} & \multirow{3}{*}{3.37} \\
\hline PHARM Syrian), & 10.2 & $0.80<4.303$ & & \\
\hline $10 \mathrm{mg} / 2 \mathrm{~mL}$ & $9.85 \pm 0.332$ & & & \\
\hline $\begin{array}{l}\text { Metoclopramide, injection } \\
\text { (GLAND PHRMA LIMITED, } \\
\text { India), } 10 \mathrm{mg} / 2 \mathrm{~mL}\end{array}$ & $\begin{array}{l}9.80 \\
9.56 \\
10.1 \\
9.82 \pm 0.271\end{array}$ & $\begin{array}{l}\mathrm{t}_{\mathrm{cal}}=1.15 \\
1.15<4.303\end{array}$ & -0.18 & 2.76 \\
\hline Metoclopramide - injection & 9.70 & & \multirow{4}{*}{-0.07} & \multirow{4}{*}{4.06} \\
\hline (hamelnpharmaceuticals & 9.70 & $\mathrm{t}_{\mathrm{cal}}=0.29$ & & \\
\hline gmbh Langes Feld 13 & 10.4 & $0.29<4.303$ & & \\
\hline Germany), $10 \mathrm{mg} / 2 \mathrm{~mL}$ & $9.93 \pm 0.404$ & & & \\
\hline
\end{tabular}


Table 7. Determination of MCP.HCl drug in pharmaceutical by the proposed method (B) and statistical comparison with quoted values

\begin{tabular}{|c|c|c|c|c|}
\hline $\begin{array}{l}\text { Commercial name } \\
\text { and content }\end{array}$ & $\begin{array}{c}\text { Practical content, } \\
\mathrm{mg} / 2 \mathrm{~mL} \\
\text { (proposed method) }\end{array}$ & $\begin{array}{c}\mathrm{t}=(\overline{\mathrm{x}-\mu}) \sqrt{\mathrm{n}} / \mathrm{s} \\
\text { Proposed method Vs. } \\
\text { claimed value at } 95 \% \text { C.I. }\end{array}$ & $\% \mathrm{E}_{\text {rel }}$ & $\begin{array}{c}\% \mathrm{RS} \\
\mathrm{D} \\
(\mathrm{n}=3) \\
\end{array}$ \\
\hline $\begin{array}{c}\text { Metoclopramide - METAMID } \\
\text { injection ((IBN HAYYAN } \\
\text { PHARM Syrian), } \\
10 \mathrm{mg} / 2 \mathrm{~mL}\end{array}$ & $\begin{array}{c}9.80 \\
9.96 \\
9.97 \\
9.91 \pm 0.10\end{array}$ & $\begin{array}{c}\mathrm{t}_{\mathrm{cal}}=1.63 \\
1.63<4.303 \\
\mathrm{p}=0.224\end{array}$ & -0.09 & 1.01 \\
\hline $\begin{array}{l}\text { Metoclopramide, injection } \\
\text { (GLAND PHRMA LIMITED, } \\
\text { India), } 10 \mathrm{mg} / 2 \mathrm{~mL}\end{array}$ & $\begin{array}{c}9.90 \\
9.96 \\
9.96 \\
9.94 \pm 0.034\end{array}$ & $\begin{array}{c}\mathrm{t}_{\mathrm{cal}}=3.000 \\
3.000<4.303 \\
\mathrm{p}=0.095\end{array}$ & -0.06 & 0.34 \\
\hline $\begin{array}{c}\text { Metoclopramide - injection } \\
\text { (hamelnpharmaceuticals gmbh } \\
\text { Langes Feld } 13 \text { Germany ), } 10 \\
\mathrm{mg} / 2 \mathrm{~mL}\end{array}$ & $\begin{array}{c}9.90 \\
9.77 \\
9.98 \\
9.95 \pm 0.0436\end{array}$ & $\begin{array}{c}\mathrm{t}_{\mathrm{cal}}=1.99 \\
1.99<4.303 \\
\mathrm{p}=0.185\end{array}$ & -0.05 & 0.44 \\
\hline
\end{tabular}

Determination of $\mathrm{MCP} . \mathrm{HCl}$ drug in pharmaceuticals

Two proposed methods were applied to assay metochlopramide hydrochloride drug in the pharmaceutical vials produced in different countries and containing $10 \mathrm{mg} / 2 \mathrm{~mL} \mathrm{MCP.HCl}$ as an active ingredient. These samples were prepared as described in the experimental part, from which each sample was submitted to the recommended CPE and $\mathrm{MCP} . \mathrm{HCl}$ drug estimated spectrophotometrically at $\lambda_{\max }$ of 530 and $490 \mathrm{~nm}$. The results presented in Table 6 and 7 revealed that the calculated $t$-values for MCP.HCl determination in different pharmaceuticals using 8-HQ and PHE as coupling reagents are less than $t$-tabulated (4.303) at $95 \%$ confidence interval and (n-1) degrees of freedom, so the null hypothesis Ho is maintained, concluding there is no evidence for systematic and random errors at the $95 \%$ confidence level and accordingly manufacturer's claims can be accepted.

\section{Applications}

According to analytical features provided by the proposed methods in aqueous solutions, the application of these methods was performed to test their truthfulness on the real samples.

\section{Determination of MCP.HCl drug in biological samples}

Since this medication like the other medicines is absorbed via the blood and excreted at a certain amount in the urine after its oral administration, it becomes necessary to estimate this drug in these vital samples. Therefore, the application of the method (A) was directed to the detection the drug $\mathrm{MCP} . \mathrm{HCl}$ in the spiked human serum and urine taken from five normal volunteers as described in the experimental section. All serum samples were spiked with $0.7 \mu \mathrm{gmL}^{-1}$ standard $\mathrm{MCP} . \mathrm{HCl}$ solutions, while the urine samples were spiked with $0.1,0.3$ and $0.7 \mu \mathrm{g} \mathrm{mL}^{-1}$, then followed the recommended CPE procedures. The results are presented in Table 8 and 9. The results revealed that good recoveries of the drug were obtained in the presence of serum or urine matrix, suggesting the established method (A) is unbiased, confirming it is relatively free from matrix interferences and with a good precision $(\mathrm{RSD}=1.04 \%)$ therefore it can be adopted in routine analysis of $\mathrm{MCP} . \mathrm{HCl}$ in the clinical quality control laboratories. 
Table 8. Determination of $\mathrm{MCP} . \mathrm{HCl}$ in human serum by proposed method (A)

\begin{tabular}{cccccc}
\hline Sample & $\begin{array}{c}\text { Mean MCP.HCl, } \\
\mu \mathrm{g} \mathrm{mL} \mathrm{mL}^{-1}\end{array}$ & $\begin{array}{c}\text { Recovery, } \\
\%\end{array}$ & $\begin{array}{c}\text { Mean } \\
\text { Recovery } \pm \text { Sd, } \%\end{array}$ & $\begin{array}{c}\mathrm{E}_{\text {rel }}, \\
\%\end{array}$ & $\begin{array}{c}\text { Mean RSD, } \\
\%(\mathrm{n}=3)\end{array}$ \\
\hline 1 & 0.720 & 102.8 & $100.92 \pm 1.05$ & 2.8 & 1.04 \\
2 & 0.703 & 100.4 & & 0.4 & \\
3 & 0.703 & 100.4 & & 0.4 & \\
4 & 0.704 & 100.5 & & 0.5 & \\
5 & 0.704 & 100.5 & & 0.5 & \\
\hline
\end{tabular}

Table 9. Determination of $\mathrm{MCP} . \mathrm{HCl}$ in human urine by proposed method (A)

\begin{tabular}{cccccc}
\hline Sample & $\begin{array}{c}\text { MCP.HCl } \\
\text { added, } \mu \mathrm{gL} \mathrm{mL}^{-1}\end{array}$ & $\begin{array}{c}\text { MCP.HCl found, } \\
\mu \mathrm{g} \mathrm{mL}^{-1}\end{array}$ & $\begin{array}{c}\text { Recovery } \\
\%\end{array}$ & $\begin{array}{c}\text { Mean } \\
\text { Recovery } \pm \text { Sd, } \%\end{array}$ & $\begin{array}{c}\text { Mean RSD, } \\
\%(\mathrm{n}=3)\end{array}$ \\
\hline \multirow{3}{*}{1} & 0.1 & 0.097 & 97.0 & $98.63 \pm 1.42$ & \\
& 0.3 & 0.298 & 99.3 & & 1.44 \\
& 0.7 & 0.697 & 99.6 & & \\
2 & 0.1 & 0.097 & 97.7 & & 1.34 \\
& 0.3 & 0.298 & 99.3 & $99.13 \pm 1.16$ & \\
3 & 0.7 & 0.702 & 100.2 & & \\
& 0.1 & 0.095 & 95.0 & & \\
& 0.3 & 0.291 & 97.0 & $97.40 \pm 2.62$ & \\
4 & 0.7 & 0.703 & 100.4 & & \\
& 0.1 & 0.095 & 95.0 & & \\
& 0.3 & 0.296 & 98.7 & $98.03 \pm 2.76$ & \\
5 & 0.7 & 0.702 & 100.2 & & \\
& 0.1 & 0.097 & 97.7 & & \\
& 0.3 & 0.297 & 99.2 & $99.10 \pm 1.35$ & \\
& 0.7 & 0.703 & 100.4 & & \\
\hline
\end{tabular}

\section{Determination of MCP.HCl drug in water}

Method B was applied to the determination of $\mathrm{MCP} . \mathrm{HCl}$ in various water samples as described in the experimental section to ensure its applicability and validity in these matrices. The results summarized in Table 10 indicated that acceptable recoveries were obtained in water matrix and therefore this method can used in the routine determination of the drug in the pollutant water.

Table 10. Determination of $\mathrm{MCP} . \mathrm{HCl}$ in water samples by proposed method (B)

\begin{tabular}{ccccccc}
\hline Sample & $\begin{array}{c}\text { MCP.HCl } \\
\text { added, } \mu \mathrm{g} \mathrm{mL}^{-1}\end{array}$ & $\begin{array}{c}\mathrm{MCP} . \mathrm{HCl} \\
\text { found, } \mu \mathrm{gL} \mathrm{m}^{-1}\end{array}$ & $\begin{array}{c}\text { Recovery, } \\
\%\end{array}$ & $\begin{array}{c}\text { Mean } \\
\text { Recovery } \pm \mathrm{Sd}, \%\end{array}$ & $\begin{array}{c}\mathrm{E}_{\text {rel }}, \\
\%\end{array}$ & $\begin{array}{c}\text { Mean RSD, } \\
\%(\mathrm{n}=3)\end{array}$ \\
\hline \multirow{2}{*}{ Tigris } & 1.0 & 0.97 & 97.0 & & -3.0 & \\
river & 3.0 & 2.86 & 95.3 & $97.27 \pm 2.11$ & -4.7 & 2.17 \\
& 6.0 & 5.97 & 99.5 & & -0.5 & \\
Baltic & 1.0 & 1.03 & 103 & & 3.0 & \\
sea & 3.0 & 2.87 & 95.6 & $99.37 \pm 3.70$ & -4.4 & 3.73 \\
& 6.0 & 5.97 & 99.5 & & -0.5 & \\
Well & 1.0 & 1.03 & 103.0 & & 3.0 & \\
& 3.0 & 2.86 & 95.3 & $99.33 \pm 3.75$ & -4.7 & 3.78 \\
& 6.0 & 5.97 & 99.5 & & -0.5 & \\
\hline
\end{tabular}




\section{Conclusion}

Two methods have been developed for the determination of drug MCP.HCl in different matrices using CPE combined with visible spectrophotometry. The methods are straight forward, fast, accurate, precise, sensitive and eco-friendly methods compared with other reported methods (c.f. Table 4). They can be easily applied to the dosage form, biological and environmental samples, particularly for waste water flowing from the medicaments industries.

\section{Acknowledgement}

The authors gratefully thank the Ministry of higher Education and Scientific Research, University of Baghdad, College of Science for Women, Iraq for the provision of a grant to Hawraa M. Abdulkareem for M.Sc study.

\section{References}

1. Thangadurai S, Shukla K and Anjaneyulum Y, Anal Sci., 2002, 18(1), 97-100; DOI:10.2116/analsci.18.97

2. Khammas Z A A, Sonnenschein L and Seuber A, Current Pharma Res., 2011, 1(3), 236-244.

3. Hilton M J, Thomas K V and Ashton D, Targeted Monitoring Programme for Pharmaceuticals in the Aquatic Environment. R\&D Technical Report P6- 012/06/TR, UK Environment Agency, Bristol, UK, 2003.

4. Boxall A B A, Kolpin D W, Halling-Sorensen B and Tolls J, Environ Sci Technol., 2003, 37(15), 286A-294A; DOI:10.1021/es032519b

5. Abreu R de Castro S C, Rodrigo Mas Ortiz R M and Jose P, Int J Pharm Pharm Sci., 2003, 6(2), 223-230.

6. Tybring G, Nordin J and Widen J, J Chromatogr B, 1998, 716(1-2), 382-386; DOI:10.1016/S0378-4347(98)00299-0

7. Olesen OV, Plougmann P and Linnet K, J Chromatogr B, 2000, 746(2), 233-239; DOI:10.1016/S0378-4347(00)00332-7

8. $\quad$ Shen Y, Zhu R-H, Li H-D, Liu Y-W and Xu P, J Pharm Biomed Anal., 2010, 53(3), 735739; DOI:10.1016/j.jpba.2010.04.031

9. Kirchherr H and Kuhn-Velten W N, J Chromatogr B, 2006, 843(1), 100-113; DOI:10.1016/j.jchromb.2006.05.031

10. Cardoso C R F, Alves M I R and Antoniosi Filho N R, Int Res J Pharma Pharmacol., 2012, 2(12), 299-305.

11. de Castro A, Concheiro M, Quintela O, Cruz A and Lopez-Rivadulla M, J Pharm Biomed Anal., 2008, 391(6), 2338-2329; DOI:10.1007/s00216-008-2135-4

12. Michael I, Hapeshi E, Michael C and Fatta-Kassinos D, Water Sci Technol., 2012, 66(7), 1574-1581; DOI:10.2166/wst.2012.350

13. Papoutsis I, Khraiwesh A, Nikolaou P, Pistos C, Spiliopoulou C and Athanaselis S, J Pharm Biomed Anal., 2012, 70, 557-76; DOI:10.1016/j.jpba.2012.05.007

14. Farghaly O A, Taher M A, Naggar A H and El-Sayed A Y, J Pharm Biomed Anal., 2005, 38(1), 14-20; DOI:10.1016/j.jpba.2004.11.059

15. El-Hefnawey G B, El-Hallag I S, Ghoneim E M and Ghoneim M M, J Pharm Biomed Anal., 2004, 34(1), 75-86; DOI:10.1016/j.japna.2003.08.008

16. Hammam E, Beltagi A M and Ghoneim M M, Microchem J, 2004, 77(1), 53-62; DOI:10.1016/j.microc.2003.12.003 
17. Kapetanović V, Milovanović L J, Aleksić M and Ignjatović L J, J Pharm Biomed Anal., 2000, 22(6), 925-932; DOI:10.1016/S0731-7085(00)00289-2

18. Al-Arfaj N A, Talanta, 2004, 62, 255-263; DOI:10.1016/j.talanta.2003.07.013

19. Xie X and Song Z, Spectrosc., 2006, 20(1), 37-43.

20. Khammas Z A A and Mubdir N S, Sci J Anal Chem., 2014, 2(5), 47-54; DOI:10.11648/j.sjac.20140205.11

21. Khammas Z A A and Mubdir N S, Chem Sci Trans., 2015, 4(2), 483-497; DOI: $10.7598 /$ cst2015.990

22. Khammas Z A A and Rashid R A, Sci J Anal Chem., 2015, 3(5), 61-70.

23. Khammas Z A A and Rashid R A, Int J Chem Sci., 2016, 14(2), 955-977.

24. Ahmad S S and Khammas Z A A, Baghdad Sci J., 2016, 13(2), 426-439.

25. Khammas Z A A and Ahmad S S, Int Res J Pure Appl Chem., 2016, 10(2), 1-16.

26. Khammas Z A A and Ahmad S S, Sci J Anal Chem., 2016, 4(3), 30-41; DOI:10.11648/j.sjac.20160403.13

27. Khammas Z A A Abdulkareem H M, Sci J Anal Chem., 2016, 4(5), 66-76; DOI:10.11648/j.sjac.20160405.12

28. British Pharmacopoeia (Her Majesty's Stationary Office, London. 2009), United States Pharmacopeia XXXII, National Formulary XXVII, US Pharmacopeial Convention,(Rockville, Maryland ,2008.

29. Page C P, Curtis M J, Sutter M C, Walker M J A and Hoffman B B, Farmacologia Integrada (Ed. Harcourt. Espana, 1998.

30. Minitab version 17, Minitab Inc., State College, PA, USA), 2014.

31. Rose J, In Advanced Physico-chemical Experiments, Pitman and Sons eds., London. P.67-69, 1964.

32. Revanasiddappa H D and Manju B, J Pharm Biomed Anal., 2001, 25(3-4), 631-637; DOI:10.1016/S0731-7085(00)00592-6

33. Shah J, Rasul Jan M, Azam Khan M and Amin S, J Anal Chem., 2005, 60(7), 633-635; DOI:10.1007/s10809-005-0151-5

34. Omran A A, Chem Pharm Bull., 2005, 53(11), 1498-1501; DOI:10.1248/cpb.53.1498

35. Revanasiddappa H D and Veena M A, Science Asia, 2006, 32, 319-321; DOI:10.2306/scienceasia1513-1874.2006.32.319

36. Guzel O and Salman A, Turkish J Pharm Sci., 2007, 4(1), 31-39.

37. Sinan R and Abed S S, Iraqi J Sci., 2009, 50(2), 136-143.

38. Sarsam L A, Mohammed S A and Al-Abbasi K M, Raf J Sci., 2011, 22(3), 76-88.

39. Devi O Z, Basavaiah K, Vinay V K B and Revanasiddappa H D, J Food Drug Anal., 2012, 20(2), 454-463.

40. Jawad A A and Kasim H K, Int J Pharm Pharm Sci., 2013, 5(3), 294-298.

41. Alshirifi A N and Abbas M H, Int J Chem Sci., 2015, 13(3), 1093-1108.

42. Ibrahim M M, Ahmed M M, Al-Amien Y A and Daf-Allah A M, Int J Innov Pharm Sci Res., 2015, 3(11), 1558-1568.

43. Solanki M J, Subrahmanyam E V S and Shabaraya A R, Res J Pharm Biol Chem Sci., 2013, 4(4), 462-478.

44. deSouza Silva M, Saraiva, L M F S, Santos J L M and Lima J F C, Spectrosc Lett., 2007, 40(1), 51-61; DOI:10.1080/00387010601093778

45. Al-Sabha T N, Al-Obaidi M T and Al-Ghabsha T S, Eur Chem Bull., 2015, 4(5), 234-239.

46. Othman N S, Mahmood H S H and Khaleel N A, Tikrit J Pure Sci., 2011, 16(4), 89-95. 